\title{
Development of Learning Devices Through Problem Based Learning Models to Improve Communication and Self-Efficacy Skills Students at Integrated Islamic Middle School Nurul 'Azizi Medan
}

\author{
Sri Ramadhani \\ Post Graduate Mathematics Education \\ State University of Medan \\ Indonesia \\ sriramdhani82@gmail.com
}

\author{
Sahat Saragih \\ Mathematics Education \\ State University of Medan \\ Medan, Indonesia
}

\author{
Amin Fauzi \\ Mathematics Education \\ State University of Medan \\ Medan, Indonesia
}

\begin{abstract}
This study aims to describe: 1) the validity of device-oriented learning models based on the developed model, 2) learning devices oriented to the development of learning problem models, 3 ) the effectiveness of device-oriented learning developed problem-based learning models, 4) improved communication skills of students using learning tools oriented to learning problems based on the developed model, 5) increasing student self-efficacy developed using learning tools oriented to problembased learning models and 6) identifying student answer processes using learning tools oriented towards developing problem-based learning models. This research is research and development, using the 4-D development model. The subjects of this study were students of class VIII-A and VIII-B. From the results of trials I and II obtained: 1) Learning tools developed are valid criteria, both in content validity and construct validity. 2) learning devices developed meet practical criteria 3) learning devices developed effective criteria, 4) there is an increase in mathematical communication skills and self-efficacy of students using developed learning tools, 5) there is an increase in student self-efficacy using model-oriented learning tools developed models problem based learning developed 6) the criteria for "good" are mostly good criteria. The process of student answers in experiment II is more structural, systematic in accordance with indicators of mathematical communication skills
\end{abstract}

Keywords- development of study peripheral, problem based learning, mathematic communication, self-efficacy student.

\section{INTRODUCTION}

Mathematics as one of the disciplines that has an important role in the world of education. The learning objectives of mathematics formulated by the National Council of Teachers of Mathematics [1] 2000 are:(1) learning to communicate (mathematical communication),(2) learning to reason (mathematical reasoning), (3) learning to solve problems(mathematical problem solving ), (4) learning to link ideas (mathematical connections),(5) the formation of a positive attitude towards mathematics (positive attitudes toward mathematics ). S ne of the aspects emphasized in the curriculum and the NCTM curriculum is to improve students' mathematical communication skills. In the process of learning mathematics mathematical communication skills are still low. The same thing also stated [2] Saragih (2007) which states: "The ability of communication in learning mathematics needs to be considered, this is due to mathematical communication can organize and consolidate students' mathematical thinking both verbally and in writing. If students have the communication skills will certainly bring students to a deep understanding of mathematics about the mathematical concepts learned.

Several factors are difficult to study mathematics another 1) trouble clicking communicate ideas into language mathematics at the time given the matter that is related to the daily life; 2) Confidence in the ability of its students in mem give reasons, ask questions and solve problems of mathematics is still lacking; 3) student mathematics as subjects boring,monotonous, and scary. Besides seeing the importance of students 'mathematical communication skills in learning, another aspect that is a problem is students' selfefficacy. [3] Bandura (1998: 2) defines self-efficacy as one's beliefs about their ability to produce performance that has an influence on their lives. To achieve the above objectives, it is necessary to have an appropriate learning model and is expected to be able to solve these problems.

Problem-based learning model, can increase student participation in the class actively, increase self-confidence and can lead to the ability to express themselves students so that high self-efficacy of students appears. The application of this learning model is strived to develop mathematical communication skills and students' self-efficacy starts working from a given problem, linking the problem to be investigated by reviewing the problem in many ways, conducting authentic 
investigations to look for real solutions to real problems, making products in the form of reports, a physical model to demonstrate to other friends, working with each other to develop social skills and thinking skills.For measure the ability of mathematical communication and self - efficacy of students, in this study developed a device problem-based learning on the material Pythagorean theorem for the eighth grade students of SMP, which includes Learning Implementation Plan (RPP), Books Teacher (BG), Books Students (BS), Student Activity Sheet (LAS) and mathematics communication skills and self-efficacy test questions . Device may study is all teaching materials arranged in a systematic and are used in the learning activities to create conducive learning atmosphere so that learning objectives can be achieved.

Development of learning tools using the 4-D model consisting of Define, Design, Develop, and Disseminate. [4] According to Nieveen (2007: 26) there are criteria in determining the quality of the results of development of learning devices,

namely (1) validity (valid); (2) practivally (practical)

(3) effectiveness (effective) . .

\section{RESEARCH METHOD}

Research is categorized into types of research and development (development research) using instructional software development models Thiagarajan 4-D. In this study developed is a learning tool with problem-based learning, including books teacher, student books, sheet student activity (LAS), lesson plan (RPP), tests the ability of mathematical communication, and questionnaires Self-efficacy research was conducted in SMP Is lam Integrated Nurul 'Azizi Medan in the even semester of the Academic Year 2017/2018 in class VIII. This study was conducted in 5 ( five ) meetings for one trial. While the object in this study was a learning tool based on problem based learning on the Pythagorean theorem material.

\section{DATA ANALYSIS, RESULT AND DISCUSSION}

Try research instruments mathematical communication ability test for 3 essay with significant level of $5 \%$, df $=28$, obtained $\mathrm{t}_{\text {table }}=2.048$. If referring to the testing criteria, the test criteria are $\mathrm{t}_{\text {arithmetic }}>\mathrm{t}_{\text {table, }}$, then the mathematical communication ability test can be used or valid.

The results of a self-efficacy questionnaire research instrument for 24 statements with a significance level of 5\%, $\mathrm{dk}=22$, obtained Table $=2.048$. If referring to the test criteria, the test criteria are $\mathrm{t}_{\text {arithmetic }}>\mathrm{t}_{\text {table, }}$, then the self efficacy questionnaire can be used or valid. Description increase students' mathematical communication skills using learning tools based PBM developed in the trials I and II are shown at $\mathrm{t}$ abel in below :

\begin{tabular}{|l|l|l|}
\hline Information & $\begin{array}{l}\text { Posstest Mathematical } \\
\text { Communication Trial I }\end{array}$ & $\begin{array}{l}\text { Posstest } \\
\text { Mathematical } \\
\text { Communication } \\
\text { Trial II }\end{array}$ \\
\hline The highest score & 87.50 & 93.75 \\
\hline Lowest Value & 56.25 & 68.75 \\
\hline Average & 74.17 & 80.42 \\
\hline
\end{tabular}

The result of the analysis of the increase in mathematical communication skills in the results of the first test posttest was 74,17 increased to 80.42 in the second trial or an increase in the average value of students' mathematical communication abilities by $8.43 \%$.

Furthermore, the improvement of communication capabilities mathematical description of the student den $\mathrm{g}$ 's using learning tools developed by PBM trials I and II trials for each indicator of students' mathematical communication $d$ apat seen on $\mathrm{t}$ abel follows:

\begin{tabular}{|c|c|c|c|c|}
\hline \multirow{2}{*}{$\begin{array}{l}\text { Mathematical } \\
\text { Communication } \\
\text { Indicator }\end{array}$} & \multicolumn{4}{|c|}{ Average } \\
\hline & $\begin{array}{c}\text { Trial } \\
\text { I }\end{array}$ & $\begin{array}{c}\text { Trial } \\
\text { II }\end{array}$ & $\begin{array}{c}\text { Enhance } \\
\text { ment }\end{array}$ & $\%$ \\
\hline $\begin{array}{l}\text { Make and } \\
\text { investigate } \\
\text { mathematical } \\
\text { guesses }\end{array}$ & 2.50 & 2.68 & .18 & $7.20 \%$ \\
\hline $\begin{array}{l}\text { Draw conclusions } \\
\text { from an argument }\end{array}$ & 2.50 & 2.6 & .10 & $4.00 \%$ \\
\hline $\begin{array}{lr}\text { Checking } & \text { the } \\
\text { validity } & \text { of } \\
\text { an argument } & \\
\end{array}$ & 2.70 & 2.93 & 0.23 & $8.52 \%$ \\
\hline $\begin{array}{l}\text { Finding patterns } \\
\text { in a mathematical } \\
\text { phenomenon. }\end{array}$ & 1.67 & 1.97 & 0.30 & $17.96 \%$ \\
\hline
\end{tabular}

For more details can be seen in the $\mathrm{x}$ following picture :

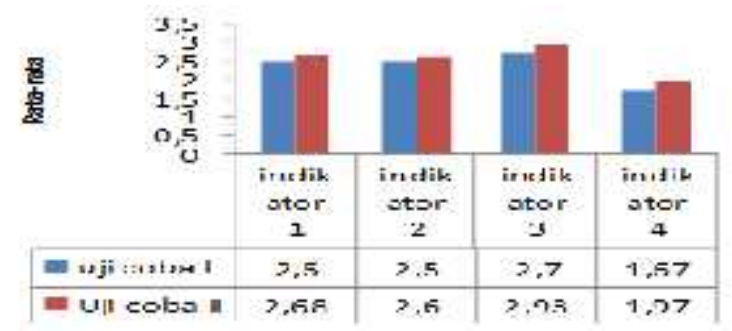

Based on table above it was concluded that the students' mathematical communication ability of the first trial to trial II seen from the average value of the total and average value

Description of the increase in self-efficacy of students after the implementation of learning tools developed by PBM shown in $\mathrm{t}$ abel follows. 


\begin{tabular}{|c|c|c|c|c|}
\hline \multirow[t]{2}{*}{ No } & \multirow[t]{2}{*}{$\begin{array}{l}\text { Self-Efficacy } \\
\text { Indicator }\end{array}$} & \multicolumn{2}{|c|}{$\begin{array}{l}\text { Average } \\
\text { Indicator }\end{array}$} & \multirow[t]{2}{*}{$\begin{array}{l}\text { Average } \\
\text { Improvement }\end{array}$} \\
\hline & & Trial I & $\begin{array}{l}\text { Trial } \\
\text { II }\end{array}$ & \\
\hline 1 & $\begin{array}{l}\text { Experience of } \\
\text { success }\end{array}$ & 16.70 & 21.20 & 4.50 \\
\hline 2 & $\begin{array}{l}\text { Other individual } \\
\text { experiences }\end{array}$ & 13.07 & 19.70 & 6.63 \\
\hline 3 & Social approach & 16.17 & 19.57 & 3.40 \\
\hline 4 & $\begin{array}{l}\text { Physiological and } \\
\text { emotional state }\end{array}$ & 15.73 & 19.37 & 3.64 \\
\hline \multicolumn{2}{|c|}{$\begin{array}{l}\text { Average Total of All } \\
\text { Indicators For Each Trial }\end{array}$} & 61.67 & 99.77 & \\
\hline \multicolumn{4}{|c|}{$\begin{array}{l}\text { Average Total Improvement of All Indicators } \\
\text { from Trial I to Trial II }\end{array}$} & 38.10 \\
\hline
\end{tabular}

For more details, we can see in the following diagram presented in Figure

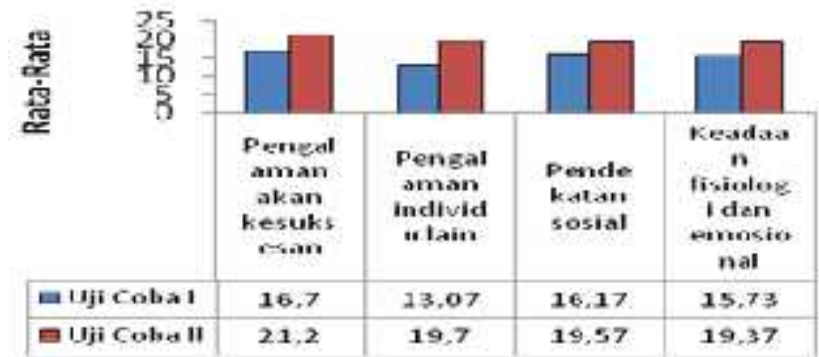

After the revision, the trial and error II in class VIII$\mathrm{B}$ obtained the results that the problem-based learning device that was developed met the practical, and effective criteria.

\section{CONCLUSION}

1. Learning devices oriented to problem-based learning models that are developed fullfill each of the practical writers. The practical criteria are reviewed from: (1) Validating the validator of learning devices can be softened easily, (2) the implementation of learning devices on trial II reaches $4<\mathrm{P} \leq 5$ with the highest category.

2. Learning-oriented sets of learning models based on problem-based learning meet effective criteria. The effectiveness criteria were reviewed from: (1) completeness of classical student learning with a score of at least 75 which had obtained $86.67 \%$ in trial II; (2) the activities of all aspects taken are based on the tolerance of the ideal time determined; and (3) positive responses of students reached $86.67 \%$ of the components of the device and learning activities.

3. Communication ability of students with increased students by $8.43 \%$ using problem-based learning tools that are developed. Improvement is assessed based on the post-test value of student trials.

4. Self-efficacy analysis was increased by 38.10 or $61.78 \%$ using the problem-based learning tool developed. Improvement was assessed based on the value of self-efficacy analysis of trial try II trial II .

\section{References}

[1] Arikunto, S. (2007). Fundamentals of Educational Evaluation . Jakarta: Bumi Aksara.

[2] Bandura, A. ( 1997). Self Efficacy: The Exercise of Control. New York: WH Freeman and Company.

[3] NCTM, 1996 , Curriculum and Evaluation Standards for School Mathematics, Virginia : NCTM.

[4] NCTM. 2000. Principles and Standards for School Mathematics . USA: NCTM. 